\title{
EFEKTIVITAS PELATIHAN EFIKASI DIRI DALAM MENINGKATKAN MOTIVASI BELAJAR MATEMATIKA SISWA SEKOLAH MENENGAH PERTAMA
}

\author{
Isnaini Oktaverina dan H. Fuad Nashori \\ Fakultas Psikologi dan Ilmu Sosial Budaya Universitas Islam Indonesia \\ Email: okta.isna@yahoo.co.id
}

\begin{abstract}
This research aimed to determine the effect of self efficacy training on students mathematics learning motivation. Subject in this research were 25 students of class IX SMP N "X" Sleman Yogyakarta, which are divided into 13 students as the experimental group and 12 students as the control group. The data was collected using a scale of mathematics motivation to learn and scale of self efficacy. The research design used was pre post control group design. Analysis of the study were quantitative and qualitative analysis. Quantitative analysis using the Mann - Whitney test to determine mathematics learning motivation after the self efficacy training given. The qualitative analysis was done based on observation, interviews and worksheets. The results of the research were used pre-test and post-test, showed that there was increased mathematics learning motivation after training given by the value of $Z=-3.740$ dan $p=0,000$ ( $p<$ $0,05)$. In the pre-test and follow-up, showed that there was increased mathematics learning motivation after two weeks of training given by the value of $Z=1.989$ dan $p=$ $0,047(\mathrm{p}<0,05)$. The conclusion of this research is the self efficacy training can increased students mathematics learning motivation class IX SMP N "X".
\end{abstract}

Key words: Self Efficacy Training, Mathematics Learning Motivation.

\begin{abstract}
Abstrak
Motivasi belajar Matematika merupakan salah satu hal yang berpengaruh pada aktivitas belajar Matematika dan berdampak pada prestasi akademik. Kenyataannya, banyak siswa memiliki motivasi belajar Matematika yang rendah. Penelitian ini bertujuan untuk mengetahui pengaruh pelatihan efikasi diri pada motivasi belajar Matematika siswa. Subjek dalam penelitian ini adalah 25 siswa kelas IX SMP Negeri "X" Sleman Yogyakarta, yang dibagi menjadi 13 siswa sebagai kelompok eksperimen dan 12 siswa sebagai kelompok kontrol. Pengumpulan data dilakukan dengan menggunakan skala motivasi belajar Matematika dan skala efikasi diri. Rancangan penelitian yang digunakan adalah pre post control group design. Analisis kuantitatif dengan menggunakan Uji Mann - Whitney untuk mengetahui motivasi belajar Matematika siswa setelah diberi pelatihan efikasi diri. Analisis kualitatif dilakukan berdasarkan observasi, wawancara, dan lembar kerja. Hasil penelitian yaitu pra-tes dan pasca-tes menunjukkan ada peningkatan motivasi belajar Matematika setelah diberi pelatihan efikasi diri, dengan nilai $\mathrm{Z}=-3.740$ dan $\mathrm{p}=0,000(\mathrm{p}<0,05)$. Pada prates dan tindak lanjut menunjukkan ada peningkatan motivasi belajar Matematika setelah dua minggu diberi pelatihan efikasi diri, dengan nilai $Z=1.989$ dan $p=0,047(p<0,05)$. Kesimpulan penelitian ini adalah pelatihan efikasi diri dapat meningkatkan motivasi belajar Matematika siswa kelas IX SMP N "X".
\end{abstract}

Kata-kata kunci: Pelatihan Efikasi Diri, Motivasi Belajar Matematika. 
$P^{2}$ roses pendidikan di sekolah merupakan kegiatan belajar yang bertujuan. Tujuan yang dimaksud adalah tercapainya hasil belajar yang optimal pada mata pelajaran yang dipelajari. Salah satunya adalah mata pelajaran matematika. Matematika merupakan bidang studi yang dipelajari oleh semua siswa dari SD hingga SLTA dan bahkan perguruan tinggi. Lebih dari itu, matematika merupakan mata pelajaran yang dujikan pada ujian kahir nasional di setiap jenjang pendidikan. Menurut Russefendi (2006) matematika adalah ratunya ilmu (mathematics is the queen of the sciences) maksudnya matematika tidak bergantung kepada bidang studi lain.

Matematika merupakan pelajaran dasar yang harus dikuasai oleh setiap siswa. Oleh karena itu, diharapkan siswa memiliki semangat dalam belajar matematika, agar mampu memahami pelajaran matematika dengan baik dan berdampak pada nilai yang baik dalam Ujian Nasional. Akan tetapi, pada kenyataannya banyak siswa yang tidak menyukai bahkan menganggap matematika sebagai pelajaran yang menakutkan untuk dipelajari. Seperti yang dikemukakan Ruseffendi (2006) bahwa matematika (ilmu pasti) bagi anak-anak pada umumnya merupakan mata pelajaran yang tidak disenangi, kalau bukan pelajaran yang paling dibenci. Hal ini dapat mempengaruhi perkembangan belajar matematika dan menurunnya motivasi belajar matematika siswa serta berdampak pada hasil belajarnya. Keberhasilan siswa dalam belajar dipengaruhi oleh faktor internal dan eksternal. Salah satu faktor yang memengaruhi hasil belajar siswa adalah motivasi belajar.

McCown, Priscaoll, \& Ropp (1996) menyatakan bahwa motivasi belajar merupakan suatu disposisi yang dimiliki oleh siswa, ditandai dengan kesediaan mereka untuk memulai aktivitas belajar, kemudian dilanjutkan dengan keterlibatan mereka dalam suatu tugas pelajaran, serta komitmen jangka panjang mereka untuk belajar. Tanpa motivasi, proses pembelajaran akan sulit mencapai kesuksesan yang optimal. Siswa yang bermotivasi tinggi dalam belajar memungkinkan akan memperoleh hasil belajar yang tinggi pula, artinya semakin tinggi motivasinya, semakin tinggi intensitas usaha yang dilakukan untuk memperoleh hasil belajar yang optimal (Hamdu \& Agustina, 2011). Walaupun demikian, motivasi belajar bagi siswa dapat menjadi lemah. Lemahnya motivasi atau tidak adanya motivasi belajar akan melemahkan kegiatan belajar dan berpengaruh buruk pada bidang akademik (Syah, 2007).

Menurut Abror (2003), gejala yang menunjukkan kurangnya motivasi belajar siswa, antara lain berkurangnya perhatian para siswa dalam proses belajar mengajar, kelalaian dalam menyelesaikan tugas-tugas yang harus dikerjakan, penundaan persiapan untuk ulangan atau ujian, atau memilih untuk membolos dibandingkan mengikuti pelajaran di kelas. Perilaku ini umumnya banyak ditemukan pada remaja yang baru memulai pendidikan sekolah menengah pertama atau SMP. Oleh karena itu, perlu adanya upaya untuk meningkatkan motivasi belajar, agar proses dan hasil belajar dapat dicapai secara optimal.

Santrock (2008) mengungkapkan faktorfaktor yang memengaruhi motivasi belajar terdiri atas faktor internal dan eksternal. Faktor internal yang memengaruhi motivasi belajar antara lain tujuan belajar, persepsi siswa mengenai kecerdasannya, dan keyakinan akan kemampuannya. Siswa yang yakin akan kemampuannya akan menunjukkan usahausaha dalam belajar sehingga yakin bahwa mereka dapat menguasai materi pelajaran (Santrock, 2008). Keyakinan bahwa diri memiliki kemampuan melakukan tindakan yang diharapkan merupakan bentuk dari Efikasi diri (Alwisol, 2004). Bandura (1997) menjelaskan bahwa efikasi diri mempunyai peran penting pada pengaturan motivasi seseorang. Seseorang percaya akan kemampuannya memiliki motivasi tinggi dan berusaha untuk sukses.

Efikasi diri mengacu pada keyakinan akan kemampuan diri untuk menggerakan motivasi, kemampuan kognitif serta tindakan yang diperlukan untuk memenuhi tuntutan situasi (Bandura, 1997). Teori efikasi diri 
berpendapat bahwa penilaian siswa mengenai apa yang bisa dilakukan dengan keterampilannya merupakan suatu mekanime yang digunakan siswa untuk mencapai keberhasilan di sekolah (Bandura, 1997). Seorang siswa di sekolah membutuhkan efikasi diri sebagai keyakinan terhadap kemampuan mereka dalam mengelola keinginan untuk berhasil atas tindakan mereka sendiri. Ketika seseorang memiliki efikasi diri maka akan memahami lebih dalam apa yang menjadi kebutuhannya dan apa yang akan dilakukannya, sehingga akan mengarahkan pada pembentukan cita-citanya sendiri (Bandura, 1997). Peneliti memberikan intervensi berupa pelatihan efikasi diri kepada siswa-siswa di SMP N "X" sebagai upaya untuk mengatasi masalah rendahnya motivasi belajar Matematika siswa.

Penelitian korelasional yang dilakukan Novariandhini dan Latifah (2012) dan Hasan dan Istiqomah (2011) tentang efikasi diri dan motivasi berprestasi, menunjukkan adanya hubungan yang positif dan signifikan antara variabel efikasi diri dengan motivasi berprestasi. Artinya, semakin baik efikasi diri yang dimiliki seorang siswa maka semakin tinggi motivasi belajar baik instrinsik maupun ekstrinsik yang dimiliki siswa dalam meraih prestasi akademik. Penelitian yang dilakukan Schunk (1991) menunjukkan bahwa siswa dengan efikasi diri yang baik terhadap kemampuan mereka untuk menyelesaikan kegiatan akademik dapat memengaruhi motivasi dan belajar. Perasaan yang tinggi terhadap efikasi diri memengaruhi seorang siswa memilih aktivitas yang diyakini akan memberikan hasil dalam belajar, serta meningkatkan motivasi.

Penelitian eksperimen yang dilakukan oleh Rohmah (2007) kepada 28 mahasiswa fakultas Psikologi yang sedang mengerjakan skripsi, menunjukkan bahwa pelatihan efikasi diri efektif dapat menurunkan stress pada mahasiswa yang sedang skripsi. Berdasarkan analisis individual, pelatihan efikasi diri memberikan manfaat diantaranya mengetahui potensi diri, mengatur waktu, menambah wawasan tentang penulisan skripsi, optimis dan yakin dalam menyelesaikan skripsi serta pekerjaan lain, sadar kekurangan diri dan termotivasi untuk belajar, berani menghadapi masalah dan mengetahui strategi mengatasi masalah-masalah skripsi dan masalah-masalah hidup.

Pelatihan efikasi diri ini disusun dengan memberikan pengetahuan untuk membantu siswa mengembangkan efikasi diri guna membangkitkan motivasi belajar terutama dalam pelajaran Matematika. Pelatihan efikasi diri dalam pelaksanaannya akan menggunakan modul sebagai sarana penyampaian pelatihan. Bandura (1997) memaparkan bahwa, teori efikasi diri memberikan penjelasan suatu model pengukuran yang tepat berhubungan dengan bentuk yang sudah diusulkan. Keyakinan efikasi harus diukur dalam bentuk penilaian yang istimewa atas kapasitas individu yang mungkin bervariasi pada berbagai bidang aktivitas, dengan tingkatan yang berbeda pada tuntutan tugas dalam area aktivitas yang diberikan, dan dengan keadaan situasional yang berbeda. Bandura (Zimmerman, 2000) juga menjelaskan bahwa, efikasi diri individu bervariasi pada beberapa aspek yang memiliki implikasi penting terhadap kinerja (prestasi). Aspek-aspek tersebut adalah Level/Magnitude, Strength, dan Generality Bandura (1997).

Penjabaran dari masing-masing dimensi tersebut yang kemudian menjadi empat materi yaitu: (1) pengenalan potensi diri, (2) membangun persepsi positif, (3) manajemen waktu, (4) daya juang. Pada sesi pengenalan potensi diri (Strength), siswa yang mampu mengenali potensi dirinya dapat memunculkan energi atau kekuatan yang bersifat internal dalam diri siswa yang berfungsi mendorong keinginan atau inisiatif siswa untuk belajar. Sesi membangun persepsi positif (Strength), siswa yang memiliki persepsi positif pada tugas-tugas akademiknya, akan memengaruhi perilaku dan pembentukan sikap dalam belajar untuk mencapai tuntutan dalam bidang akademik. Siswa yang memiliki persepsi positif akan kemampuannya merupakan salah satu faktor internal yang memengaruhi motivasi belajar siswa (Santrock, 2008). 
Pada sesi manajemen waktu (generality), siswa yang memiliki perencanaan waktu, menunjukkan adanya bentuk monitoring diri dan komitmen dalam kegiatan belajar. Hal ini dapat membantu siswa untuk mempertahankan kegiatan belajar yang dipilihnya dalam menyelesaikan tugas akademik yang dibatasi tenggat waktu. Pearl et. al. (Mukhid, 2009) menyatakan bahwa siswa dengan efikasi diri yang tinggi memiliki monitoring diri yang lebih baik terhadap hasil belajar mereka daripada siswa yang memiliki efikasi diri rendah. Sedangkan pada sesi daya juang (Level), ketika siswa menyadari pentingnya memiliki daya juang, maka siswa akan mempunyai banyak energi untuk melibatkan diri baik secara mental maupun fisik dalam proses belajar.

Pelatihan efikasi diri ini diharapkan memberikan keterampilan kepada siswa untuk mengembangkan pengetahuan kecakapan dan kemampuan mengenai efikasi diri siswa dalam melaksanakan serta menyelesaikan tugas-tugas akademik yang dihadapi terutama dalam pelajaran Matematika. Dengan demikian, siswa termotivasi untuk belajar Matematika agar dapat meraih hasil akademik sesuai harapannya.

\section{METODE}

\section{Partisipan}

Subjek pada penelitian ini adalah 25 siswa kelas IX SMP N "X" Sleman Yogyakarta. Penentuan subjek berdasarkan pada hasil skor motivasi belajar Matematika dan skor efikasi diri yang termasuk dalam kategori sedang-rendah. Dari 25 siswa yang memiliki skor motivasi belajar Matematika dan skor efikasi diri sedang-rendah, peneliti membagi 25 siswa tersebut menjadi dua kelompok berdasarkan kelas yaitu 13 siswa (kelas IX B) untuk kelompok eksperimen dan 12 siswa (kelas IX A dan IX C) untuk kelompok kontrol.

Subjek yang diberikan pelatihan diambil berdasarkan skor hasil pengisian alat ukur motivasi belajar Matematika dan efikasi diri. Setelah ditemukan beberapa siswa yang memiliki motivasi belajar dan efikasi diri kategori sedang hingga rendah. Adapun pemberian skala efikasi diri Matematika hanya digunakan sebagai tambahan screening awal dalam menentukan subjek. Pembagian kelompok menggunakan teknik purposive sampling, yaitu teknik penentuan sampel dengan pertimbangan tertentu (Sugiyono, 2010). Pertimbangan penentuan subjek dalam penelitian ini adalah jumlah subjek terbanyak dalam satu kelas yang memiliki karakteristik sama setelah dilakukan pra-tes. Cara ini juga digunakan untuk menghindari atau menjaga agar perlakuan yang akan diberikan kepada siswa kelompok eksperimen tidak diketahui oleh siswa dari kelas lain yang tidak mendapat perlakuan (kelompok kontrol).

\section{Rancangan Penelitian}

Penelitian ini merupakan penelitian eksperimen dengan menggunakan variabel bebas berupa efikasi diri, variabel terikat berupa motivasi belajar Matematika. Rancangan ekperimen yang digunakan adalah pre post control group design. Pada desain ini, diawal penelitian dilakukan pengukuran terhadap variabel tergantung pada subjek. Kemudian setelah diberikan perlakuan dilakukan pengukuran kembali terhadap variabel tergantung pada subjek dengan alat ukur yang sama (Azwar, 2007).

Rancangan eksperimen yang digunakan dalam penelitian ini adalah:

\begin{tabular}{|c|c|c|c|c|}
\hline Kelompok & Pra-tes & Perlakuan & Pasca-tes & Tindak lanjut \\
\hline Eksperimen & $\mathrm{Y} 1$ & $\mathrm{X}$ & $\mathrm{Y} 2$ & Y3 \\
\hline Kontrol & $\mathrm{Y} 4$ & - & Y5 & Y6 \\
\hline $\begin{array}{l}\text { Teterangan }: \\
1=\text { Pra-tes ke } \\
2=\text { Pasca-tes } \\
3=\text { Tindak lan }\end{array}$ & $\begin{array}{l}\text { ompok ekspe } \\
\text { elompok eks } \\
\text { jut kelompok }\end{array}$ & $\begin{array}{l}\text { imen } \\
\text { erimen } \\
\text { eksperimen }\end{array}$ & $\begin{array}{l}\text { Y4 }=\text { Pra-tes ke } \\
\text { Y5 }=\text { Pasca-tes } \\
\text { Y6 }=\text { Tindak lar } \\
X=\text { Perlakuan }\end{array}$ & $\begin{array}{l}\text { ompok kontrol } \\
\text { elompok kontrol } \\
\text { jut kelompok kontro }\end{array}$ \\
\hline
\end{tabular}




\section{Pengumpulan Data}

Untuk memperoleh data yang akan dianalisis secara kuantitatif, alat ukur yang digunakan adalah skala motivasi belajar Matematika dan skala efikasi diri. Data untuk analisis kualitatif diperoleh berdasarkan hasil observasi partisipan selama mengikuti pelatihan efikasi diri, data lembar kerja yang diberikan, dan data evaluasi partisipan setelah mengikuti pelatihan efikasi diri.

Skala motivasi belajar Matematika pada penelitian ini digunakan sebagai alat ukur untuk mengungkap motivasi belajar Matematika siswa. Skala motivasi belajar Matematika terdiri dari 38 pernyataan. Aspekaspek yang diungkap adalah 1) keinginan atau inisiatif sendiri untuk belajar; 2) keterlibatan secara sungguh-sungguh dalam proses belajar dan tugas yang diberikan; dan 3) komitmen untuk terus belajar sehingga bertahan dalam pelajaran (Mc Cown, 1996). Sedangkan skala efikasi diri terdiri dari 23 pernyataan. Aspekaspek yang diungkap adalah 1) Level/Magnitude, 2) Strength, dan 3) Generality (Bandura, 1997).

Sebelum digunakan untuk mengambil data, dilakukan uji coba. Uji coba skala dilakukan pada 92 siswa SMP N "XX". Koefisien validitas yang digunakan yaitu koefisien validitas $\geq 0,30$. Pandangan tersebut didasarkan asumsi bahwa aitem yang valid adalah aitem yang memiliki validitas $\geq 0,30$, dengan alasan seleksi aitem untuk mengungkap aspek non-kognitif adalah dengan menggunakan koefisien validitas aitem $\geq 0,30$ (Azwar, 2012). Hasil yang diperoleh adalah sebagai berikut:

Pertama, skala motivasi belajar Matematika. Dari 38 aitem yang diujicobakan, terdapat 1 aitem tidak valid atau gugur yaitu aitem 9, kemudian didapat 37 aitem valid dengan koefisien validitas berkisar antara 0,348-0,751. Hasil uji reliabilitas dari 37 aitem valid menunjukkan koefisien reliabilitas $\alpha=$ 0,952. Menurut Azwar (2012), reliabilitas dinyatakan oleh koefisien reliabilitas (rxx') yang angkanya berada pada rentang 0 sampai 1,00. Semakin mendekati 0 semakin rendah reliabilitas skala dan semakin mendekati angka 1,00 semakin tinggi reliabiltas skala tersebut. Dengan angka koefisien reliabilitas $\alpha$ sebesar 0,952, maka dapat dikatakan bahwa hasil pengukuran skala motivasi belajar Matematika memiliki reliabilitas yang tinggi. Berdasarkan aitem-aitem yang valid tersebut, skala motivasi belajar Matematika disusun kembali dengan memberi nomor-nomor baru pada masingmasing aitem. Selanjutnya skala yang telah disusun kembali dapat digunakan sebagai alat ukur untuk prates (skala motivasi belajar Matematika).

Kedua, skala efikasi diri. Dari 23 aitem yang diujicobakan, terdapat 2 aitem tidak valid atau gugur yaitu aitem 2 dan 13, kemudian didapat 21 aitem valid dengan koefisien validitas berkisar antara 0,396-0,680. Hasil uji reliabilitas dari 21 aitem valid menunjukkan koefisien reliabilitas $\alpha=0,915$. Menurut Azwar (2012), reliabilitas dinyatakan oleh koefisien reliabilitas (rxx') yang angkanya berada pada rentang 0 sampai 1,00 . Semakin mendekati 0 semakin rendah reliabilitas skala dan semakin mendekati angka 1,00 semakin tinggi reliabiltas skala tersebut. Dengan angka koefisien reliabilitas a sebesar 0,915, maka dapat dikatakan bahwa hasil pengukuran skala efikasi diri Matematika memiliki reliabilitas yang tinggi. Berdasarkan aitem-aitem yang valid tersebut, skala efikasi diri Matematika disusun kembali dengan memberi nomor-nomor baru pada masing-masing aitem. Selanjutnya skala yang telah disusun kembali tersbut dapat digunakan sebagai alat ukur untuk prates (skala efikasi diri Matematika).

\section{Intervensi}

Intervensi yang diberikan pada kelompok eksperimen berupa pelatihan efikasi diribagi siswa yang memiliki motivasi belajar Matematika sedang-rendah. Pelatihan efikasi diri ini diharapkan memberikan keterampilan kepada siswa untuk mengembangkan pengetahuan kecakapan dan kemampuan mengenai efikasi diri siswa dalam melaksanakan serta menyelesaikan tugas-tugas akademik yang dihadapi terutama dalam pelajaran Matematika. Dengan demikian, siswa 
termotivasi untuk belajar Matematika agar dapat meraih hasil akademik sesuai harapannya. Pelatihan dilakukan dalam 2 kali pertemuan dengan 6 sesi yaitu, pembukaan, potensi diri, membangun persepsi positif, manajemen waktu, daya juang, dan penutupan.

\section{Analisis Data}

Analisis data yang digunakan adalah analisis kuantitatif dan kualitatif. Analisis kuantitatif dilakukan untuk menguji hipotesis dengan menggunakan analisis statistik berupa Uji Mann-Whitney untuk mengetahui tingkat motivasi belajar Matematika siswa setelah diberi pelatihan efikasi diriantara kelompok eksperimen dan kelompok kontrol. Semua analisis data menggunakan bantuan SPSS for Windows versi 16,0. Analisis kualitatif dilakukan secara individual dan bertujuan untuk menjelaskan proses pelatihan efikasi diri yang dialami masing-masing individu. Analisis ini dilakukan dengan mengolah data yang diperoleh dari observasi terhadap partisipan selama mengikuti pelatihan efikasi diri, data lembar kerja yang diberikan dan data evaluasi partisipan setelah mengikuti pelatihan efikasi diri.

\section{HASIL}

\section{Deskripsi Partisipan}

Ada perbedaan skor motivasi belajar Matematika pada setiap pengukuran.

\begin{tabular}{|c|c|c|c|c|c|c|c|c|c|}
\hline Subjek & $\begin{array}{l}\text { Pra } \\
\text { tes }\end{array}$ & $\begin{array}{l}\text { Kate- } \\
\text { gori }\end{array}$ & Pascates & $\begin{array}{l}\text { Kate- } \\
\text { gori }\end{array}$ & $\begin{array}{l}\text { Tindak } \\
\text { lanjut }\end{array}$ & $\begin{array}{l}\text { Kate- } \\
\text { gori }\end{array}$ & $\begin{array}{l}\text { Gain } \\
\text { Skor } \\
\text { Pra- } \\
\text { pasca }\end{array}$ & $\begin{array}{l}\text { Gain } \\
\text { Skor } \\
\text { Pra- } \\
\text { tindak } \\
\text { lanjut }\end{array}$ & $\begin{array}{l}\text { Gain } \\
\text { Skor } \\
\text { Pasca- } \\
\text { tindak } \\
\text { lanjut }\end{array}$ \\
\hline \multicolumn{10}{|c|}{ Kelompok Eksperimen } \\
\hline Subjek 1 & 100 & $\mathrm{~S}$ & 113 & $\mathrm{~T}$ & 106 & $\mathrm{~T}$ & 13 & 6 & -7 \\
\hline Subjek 2 & 98 & $S$ & 108 & $\mathrm{~T}$ & 106 & $\mathrm{~T}$ & 10 & 8 & -2 \\
\hline Subjek 3 & 94 & $S$ & 101 & $S$ & 108 & $\mathrm{~T}$ & 7 & 14 & 7 \\
\hline Subjek 4 & 101 & $S$ & 111 & $\mathrm{~T}$ & 106 & $\mathrm{~T}$ & 10 & 5 & -5 \\
\hline Subjek 5 & 92 & $S$ & 106 & $\mathrm{~T}$ & 105 & $\mathrm{~T}$ & 14 & 13 & -1 \\
\hline Subjek 6 & 92 & $S$ & 98 & $S$ & 101 & $S$ & 6 & 9 & 3 \\
\hline Subjek 7 & 86 & $S$ & 91 & $S$ & 96 & $S$ & 5 & 10 & 5 \\
\hline Subjek 8 & 95 & $S$ & 103 & $\mathrm{~T}$ & 96 & $S$ & 8 & 1 & -7 \\
\hline Subjek 9 & 87 & $S$ & 114 & $\mathrm{~T}$ & 108 & $\mathrm{~T}$ & 27 & 21 & -6 \\
\hline Subjek 10 & 93 & $\mathrm{~S}$ & 103 & $\mathrm{~T}$ & 95 & $S$ & 10 & 2 & -8 \\
\hline Subjek 11 & 101 & $\mathrm{~S}$ & 110 & $\mathrm{~T}$ & 105 & $\mathrm{~T}$ & 9 & 4 & -5 \\
\hline Subjek 12 & 100 & $\mathrm{~S}$ & 106 & $\mathrm{~T}$ & 103 & $\mathrm{~T}$ & 6 & 3 & -3 \\
\hline Subjek 13 & 92 & $S$ & 100 & $S$ & 105 & $\mathrm{~T}$ & 8 & 13 & 5 \\
\hline \multicolumn{10}{|c|}{ Kelompok Kontrol } \\
\hline Subjek 1 & 98 & $\mathrm{~S}$ & 103 & $\mathrm{~T}$ & 84 & $S$ & 5 & -14 & -19 \\
\hline Subjek 2 & 100 & $S$ & 100 & $S$ & 99 & $S$ & 0 & -1 & -1 \\
\hline Subjek 3 & 88 & $\mathrm{~S}$ & 90 & $S$ & 81 & $\mathrm{R}$ & 2 & -7 & -9 \\
\hline Subjek 4 & 96 & $\mathrm{~S}$ & 102 & $\mathrm{~T}$ & 106 & $\mathrm{~T}$ & 6 & 10 & 4 \\
\hline Subjek 5 & 96 & $\mathrm{~S}$ & 99 & $\mathrm{~S}$ & 81 & $\mathrm{R}$ & 3 & -15 & -18 \\
\hline Subjek 6 & 95 & $\mathrm{~S}$ & 93 & $S$ & 112 & $\mathrm{~T}$ & -2 & 17 & 19 \\
\hline Subjek 7 & 86 & $\mathrm{~S}$ & 85 & $\mathrm{~S}$ & 89 & $S$ & -1 & 3 & 4 \\
\hline Subjek 8 & 98 & $S$ & 102 & $\mathrm{~T}$ & 102 & $\mathrm{~T}$ & 4 & 4 & 0 \\
\hline Subjek 9 & 100 & $S$ & 102 & $\mathrm{~T}$ & 108 & $\mathrm{~T}$ & 2 & 8 & 6 \\
\hline Subjek 10 & 100 & $\mathrm{~S}$ & 108 & $\mathrm{~T}$ & 110 & $\mathrm{~T}$ & 8 & 10 & 2 \\
\hline Subjek 11 & 93 & $S$ & 94 & $\mathrm{~S}$ & 92 & $\mathrm{~S}$ & 1 & -1 & -2 \\
\hline
\end{tabular}




\begin{tabular}{|l|l|l|l|l|l|l|l|l|l|}
\hline Subjek 12 & 99 & S & 105 & T & 90 & S & 6 & -9 & -15 \\
\hline
\end{tabular}

Keterangan :

$\mathrm{R}$ : Rendah

$\mathrm{S}:$ Sedang

$\mathrm{T}$ : Tinggi

\section{Hasil Analisi Kuantitatif}

Analisis hasil dilakukan secara keseluruhan menggunakan analisis statistik uji Mann-Whitney. Priyatno (2012) mengatakan uji Mann-Whitney digunakan untuk menguji perbandingan dua rata-rata kelompok sampel (eksperimen dan kontrol) yang independen. Analisis ini termasuk non parametrik sehingga, tidak mensyaratkan data berdistribusi normal. Perhitungan selengkapnya menggunakan program Statistical Product and Service Solution (SPSS) for Windows versi 16,0. Hasil analisis data dengan uji Mann-Whitney terdapat pada tabel 12 (rangkuman Uji Mann-Whitney) di bawah ini :

\section{a. Pra-tes dan Pasca-tes}

Descriptive Statistics

\begin{tabular}{|l|l|l|l|l|l|}
\hline & $\mathrm{N}$ & Mean & Std. Deviation & Minimum & Maximum \\
\hline Motivasi Belajar & 25 & 6.6800 & 5.89293 & -2.00 & 27.00 \\
PraPasca & 25 & 1.4800 & .50990 & 1.00 & 2.00 \\
\hline
\end{tabular}

Ranks

\begin{tabular}{|ll|l|l|l|}
\hline \multicolumn{2}{|c|}{ PraPasca } & $\mathrm{N}$ & Mean Rank & Sum of Ranks \\
\hline Motivasi & 1 & 13 & 18.27 & 237.50 \\
Belajar & 2 & 12 & 7.29 & 87.50 \\
& Total & 25 & & \\
\hline
\end{tabular}

\begin{tabular}{|l|l|}
\hline & MotivasiBelajar \\
\hline Mann-Whitney U & 9.500 \\
Wilcoxon W & 87.500 \\
Z & -3.740 \\
Asymp. Sig. (2-tailed) & .000 \\
Exact Sig. [2*(1-tailed & $.000^{\mathrm{a}}$ \\
Sig.)] & \\
\hline
\end{tabular}

a. Not corrected for ties.

b. Grouping Variable: kelompok

Berdasarkan data pra-tes dan pasca-tes skala motivasi belajar Matematika siswa diketahui nilai $\mathrm{Z}=-3.740$ dengan $\mathrm{p}=0.000$ (nilai sig $<0,05$ ), yang berarti hipotesis diterima yaitu ada pengaruh pemberian pelatihan efikasi diri terhadap peningkatan

motivasi belajar Matematika. Hal ini menunjukkan adanya perbedaan motivasi belajar Matematika sebelum pelatihan efikasi diri (pra-tes) dan setelah pelatihan efikasi diri (pasca-tes). 


\section{b. Pra-tes - Tindak Lanjut}

Descriptive Statistics

\begin{tabular}{|l|l|l|l|l|l|}
\hline & $\mathrm{N}$ & Mean & Std. Deviation & Minimum & Maximum \\
\hline MotivasiBelajar & 25 & 4.5600 & 8.94930 & -15.00 & 21.00 \\
PraTindakLanjut & 25 & 1.4800 & .50990 & 1.00 & 2.00 \\
\hline
\end{tabular}

Ranks

\begin{tabular}{|ll|l|l|l|}
\hline & PraTindakLanjut & N & Mean Rank & Sum of Ranks \\
\hline MotivasiBelajar & 1 & 13 & 15.81 & 205.50 \\
& 2 & 12 & 9.96 & 119.50 \\
& Total & 25 & & \\
\hline
\end{tabular}

\begin{tabular}{|l|l|}
\hline & Motivasi Belajar \\
\hline Mann-Whitney U & 41.500 \\
Wilcoxon W & 119.500 \\
Z & -1.989 \\
Asymp. Sig. (2-tailed) & .047 \\
Exact Sig. [2*(1-tailed Sig.)] & $.046^{\mathrm{a}}$ \\
\hline
\end{tabular}

a. Not corrected for ties.

b. Grouping Variable: Kelompok

Motivasi belajar Matematika kemudian dilihat lagi oleh peneliti 2 minggu setelah pelatihan (tindak lanjut). Berdasarkan data prates dan tindak lanjut skala motivasi belajar Matematika siswa diketahui nilai $\mathrm{Z}=-1.989$ dengan $\mathrm{p}=0.047$ (nilai sig $<0,05$ ), yang berarti hipotesis diterima yaitu ada pengaruh pemberian pelatihan efikasi diri terhadap peningkatan motivasi belajar Matematika. Hal ini menunjukkan adanya perbedaan motivasi belajar Matematika antara kelompok eksperimen dan kelompok kontrol sebelum pelatihan efikasi diri (pra-tes) dan dua minggu setelah pelatihan efikasi diri (tindak lanjut).

Dari 13 subjek pelatihan, ada sembilan subjek yang mengalami peningkatan motivasi belajar Matematika (kategori sedang ke kategori tinggi) setelah diberikan pelatihan (pasca-tes). Sedangkan empat subjek mengalami peningkatan skor namun tetap dalam kategori yang sama yaitu sedang. Dua minggu setelah pelatihan (tindak lanjut), 2 subjek mengalami penurunan (kategori tinggi ke kategori sedang) walaupun tidak sampai dalam kondisi semula, dan 2 subjek mengalami peningkatan skor, namun tetap dalam kategori sedang.

\section{PEMBAHASAN}

Penelitian ini bertujuan untuk mengetahui pengaruh pelatihan efikasi diri terhadap peningkatan motivasi belajar Matematika pada siswa Sekolah Menengah Pertama (SMP) yang terbagi dalam kelompok eksperimen dan kelompok kontrol. Berdasarkan analisis data yang telah dilakukan secara kuantitatif, didapatkan nilai $\mathrm{Z}=-3.740$ dengan $\mathrm{p}=0.000$ (nilai sig < 0.05). Hal ini menunjukkan adanya perbedaan motivasi belajar Matematika sebelum pelatihan efikasi diri (pra-tes) dan setelah pelatihan efikasi diri (pasca-tes). Kemudian, dua minggu setelah pelatihan dilakukan pengukuran kembali (tindak lanjut) dan didapatkan nilai $\mathrm{Z}=-1.989$ dengan $\mathrm{p}=$ 
0.47 (nilai sig < 0.05). Hal ini juga menunjukkan adanya perbedaan motivasi belajar Matematika sebelum pelatihan efikasi diri (prates) dan dua minggu setelah pelatihan (tindak lanjut). Dengan demikian, hipotesis dalam penelitian ini diterima, yaitu ada pengaruh pemberian pelatihan efikasi diri terhadap peningkatan motivasi belajar Matematika.

Kelompok eksperimen, yaitu siswa yang diberikan pelatihan efikasi diri mengalami peningkatan motivasi belajar Matematika lebih tinggi dibandingkan kelompok kontrol, yaitu siswa yang tidak mendapatkan pelatihan efikasi diri.

Diterimanya hipotesis yang diajukan dalam penelitian ini mendukung pendapat Bandura (1997) bahwa efikasi diri memberikan pengaruh dan kontribusi atas motivasi yang kuat pada diri seseorang. Efikasi diri merupakan unsur pokok dalam menunjang usaha mencapai kesuksesan. Efikasi diri yang tinggi mengerahkan usaha yang lebih besar daripada efikasi diri rendah. Penelitian yang dilakukan Bandura (1994) juga mengatakan bahwa individu yang kuat efikasi dirinya akan meningkatkan prestasi pribadi dan kesejahteraannya dalam berbagai strategi. Jika siswa memiliki efikasi diri tinggi, maka ia cenderung untuk memilih tugas yang menantang dan lebih siap untuk menghadapi suatu tugas atau ujian serta optimis mencapai keberhasilan. Penelitian Colquit (Hariyanto dkk, 2011) juga menunjukkan bahwa efikasi diri mempunyai hubungan yang kuat dengan motivasi belajar dan transfer pelatihan.

Efikasi diri merupakan faktor penentu proses kemunculan motivasi yang mendorong seorang individu melakukan suatu perilaku. Tanpa efikasi diri yang positif, individu akan merasa ragu atau bahkan tidak termotivasi untuk melakukan suatu kegiatan. Siswa yang memiliki efikasi diri positif cenderung mempunyai motivasi yang lebih besar untuk melaksanakan tugas sesuai target yang ditetapkan. Keyakinan akan kemampuan diri mendorong siswa berbuat lebih efektif dalam berusaha dengan memilih langkah-langkah yang akan ditempuh untuk menyelesaikan suatu tugas. Semakin tinggi efikasi diri siswa semakin kuat motivasinya untuk berprestasi.

Pelatihan efikasi diri merupakan suatu program yang disusun dengan memberikan pengetahuan untuk membantu siswa mengembangkan efikasi diri guna membangkitkan motivasi belajar terutama dalam pelajaran Matematika. Adapun isi materi dan desain pelatihan yang digunakan dalam penelitian ini disusun menggunakan modifikasi aspek-aspek efikasi diri dari Bandura (1997), yaitu Level/Magnitude, Strength, dan Generality. Pendekatan pelatihan dipilih karena pelatihan merupakan suatu metode pembelajaran yang bertujuan untuk mengubah aspek kognitif, afektif, serta hasil keterampilan atau keahlian (Kikpatrick dalam Salas dkk, 2001). Pada pelatihan efikasi diri didasarkan pada teori experiental learning, yang menunjukkan bahwa pelatihan mampu mengubah struktur kognitif, sikap serta keterampilan yang dimiliki oleh peserta. Melalui pelatihan pertama-tama peserta diarahkan untuk menyadari suatu keterampilan dikuasai dan komponen-komponen atau langkah-langkah yang perlu dilakukan agar suatu keterampilan dapat dikuasai dengan baik. Salah satu kelebihan pelatihan adalah dalam pelatihan individu tidak belajar seorang diri, tetapi belajar dalam suatu kelompok, karena pelatihan diikuti oleh lebih dari satu peserta.

Johnson dan Johnson (2001) menyatakan bahwa metode pelatihan berdasarkan prinsip experiental learning, yaitu bahwa perilaku manusia terbentuk berdasarkan hasil pengalaman yang terlebih dahulu dimodifikasi untuk menambah efektivitas. Semakin lama perilaku tersebut menjadi suatu kebiasaan dan berjalan otomatis, maka individu akan semakin berusaha memodifikasi perilaku yang sesuai dengan situasi yang dihadapinya. Experiental learning sendiri ada lima tahapan, yaitu experiencing, publishing, processing, generalizing dan applying (Aryani dan Supriyanto, 2003).

Berangkat dari rendahnya motivasi belajar Matematika, diperlukan adanya 
intervensi untuk meningkatkan motivasi belajar Matematika siswa. Matematika sebagai salah satu mata pelajaran yang diujikan dalam Ujian Nasional, mengharuskan siswa memperoleh nilai sesuai dengan standar nilai matematika yang telah ditetapkan agar lulus sekolah. Oleh karena itu, harapannya siswa SMP dapat serius dan semangat dalam belajar Matematika, tidak membolos, mengerjakan tugas yang diberikan oleh guru, memperhatikan penjelasan yang diberikan oleh guru, sehingga siswa mampu memahami pelajaran Matematika dengan baik dan akan berdampak pada nilai yang baik dalam ujian nasional (UN). Salah satu faktor yang berperan dalam pencapaian prestasi siswa adalah adanya motivasi belajar. Siswa juga membutuhkan motivasi belajar agar dapat mencapai prestasi akademik (Syafitri, 2004). Pada penelitian ini, peneliti memilih pelatihan efikasi diri sebagai intervensi untuk meningkatkan motivasi belajar siswa.

Berdasarkan hasil wawancara yang dilakukan setelah pelatihan berlangsung diperoleh keterangan dari peserta bahwa mereka merasa senang mendapat pengalaman dan pandangan baru menyelesaikan suatu permasalahan terutama dalam belajar Matematika. Pelatihan efikasi diri yang diberikan kepada peserta eksperimen telah menambah keyakinan dan rasa percaya diri peserta dalam menghadapi tugas Matematika serta dalam mencapai nilai UN Matematika sesuai harapannya.

Hal ini menjadikan peserta lebih termotivasi untuk belajar Matematika dan mengikuti kelas Matematika di sekolah. Keyakinan terhadap kemampuan diri sendiri akan membuat individu memiliki motivasi untuk mengerjakan segala sesuatunya dan menyelesaikan pekerjaannya dengan baik karena ia yakin bahwa dirinya mampu untuk menyelesaikan tugas tersebut (Bandura, 1993). Menurut Morris dan Summers (Novariandhini dan Latifah, 2012) karena efikasi diri mempunyai hubungan yang erat dengan motivasi maka selain berpengaruh terhadap performa, efikasi diri juga berpengaruh terhadap motivasi individu.
Sesi-sesi dalam pelatihan efikasi diri membuat para peserta mengetahui potensi yang dimiliki dan mengembangkan kemampuan yang ada dalam dirinya, sehingga dapat meningkatkan efikasi diri mereka tentang kemampuan yang selama ini telah dimiliki. Seseorang dengan efikasi diri tinggi akan mengorganisir permasalahan yang ada kemudian menentukan suatu tindakan untuk mengatasi permasalahan tersebut (Bandura, 1997). Semakin tinggi efikasi diri individu, semakin individu percaya akan kemampuannya untuk berhasil dalam suatu tugas dan akan berusaha keras dalam menghadapi tantangan yang ada. Sebaliknya, individu dengan efikasi diri yang rendah cenderung akan mengurangi usahanya atau menyerah sama sekali. Permasalahan yang dihadapi dalam hal ini adalah motivasi belajar Matematika.

Pelatihan efikasi diri ini mengajarkan keterampilan-keterampilan yang mampu mengembangkan keyakinan siswa akan kemampuannya dalam belajar Matematika melalui materi yang dimodifikasi dari dimensidimensi efikasi diri Bandura (1997). Hal tersebut yang memungkinkan terjadinya peningkatan skor motivasi belajar Matematika siswa pada kelompok eksperimen. Siswa yang mempunyai keyakinan dapat mengembangkan kemampuannya (Strength), mereka akan bertahan dalam usahanya menyelesaikan tugastugas Matematika yang sulit. Keyakinan siswa menyelesaikan tugas-tugas yang sulit (Level) membuat siswa menganggap tugas-tugas yang sulit sebagai tantangan untuk dikuasai dibanding sebagai ancaman untuk dihindari.

Keyakinan dengan ketahanan usaha dalam menghadapi taraf kesulitan tugas yang berada pada situasi yang tidak mendukung dapat meyakinkan siswa dalam mengatasai halhal tersebut, sehingga mampu menaikkan motivasi belajar siswa. Siswa yang mempunyai keyakinan dapat mengembangkan kemampuan dan menentukan target prestasi belajarnya (Generality). Hal ini akan membuat siswa lebih efisien memilih dan menata langkah-langkah yang akan dilakukan agar dapat mencapai target prestasi belajarnya. 
Penentuan target, skala prioritas, dan memiliki batas waktu biasanya akan membuat siswa lebih terpacu untuk menyelesaikan target yang dibuat. Komitmen pada tujuan yang sudah dibuat, adalah hal yang penting untuk terus berusaha dalam melaksanakan tujuan yang telah dibuat, disini siswa menuliskan komitmen berupa kalimat yang membuat dirinya tetap melaksanakan apa yang sudah dibuatnya.

Hal ini sesuai dengan pendapat yang dikemukakan oleh Pajares (2002) bahwa efikasi diri berdampak pada perilaku dalam beberapa hal yang penting. Pertama, efikasi diri dapat mempengaruhi pilihan-pilihan yang dibuat dan tindakan yang dilakukan individu dalam melaksanakan tugas-tugas dimana individu tersebut merasa berkompeten dan yakin. Keyakinan diri yang mempengaruhi pilihan-pilihan tersebut akan menentukan pengalaman dan mengedepankan kesempatan bagi individu untuk mengendalikan kehidupan. Keyakinan ini dapat menjadi dasar dalam keputusan tindakan-tindakan yang akan dilakukan selanjutnya. Kedua, efikasi diri menentukan seberapa besar usaha yang dilakukan oleh individu, seberapa lama individu akan bertahan ketika menghadapi rintangan dan seberapa tabah dalam menghadapi situasi yang tidak menguntungkan. Efikasi diri mempengaruhi tingkat prestasi belajar dan kegelisahan yang dialami individu ketika sedang melaksanakan tugas dan mempengaruhi tingkat pencapaian prestasi individu.

Faktor yang juga mendukung keberhasilan pemberian pelatihan efikasi diri selain modul materi yang diberikan kepada siswa disusun secara sistematik dan menarik adalah keterlibatan pelatih. Pelatih dapat menyampaikan materi pelatihan dengan jelas dan dapat dimengerti oleh siswa. Pengalaman, penguasaan materi, kualitas interpersonal yang baik, kerjasama antara pelatih dan asisten pelatih merupakan modal utama yang mendukung pelatih dalam menjalankan pelatihan dengan baik.
Pelatih mampu memimpin proses pelatihan dengan baik, mampu menumbuhkan suasana keterbukaan dan keakraban di antara peserta, mampu menjelaskan materi dan menjawab pertanyaan dengan bahasa yang mudah dipahami peserta sehingga menimbulkan rasa ketertarikan peserta terhadap pelatihan efikasi diri ini. Suasana keakraban yang sudah dibangun dari awal pelatihan efikasi diri dengan menggunakan ice breaking memberikan dampak yang positif bagi peserta sehingga membuat suasana hangat, lebih semangat, dan tumbuh keakraban antara peserta dan pelatih.

Beberapa penelitian sebelumnya yang relevan dengan hasil penelitian ini, yaitu penelitian Gaskill dan Murphy (2004) yang menunjukkan bahwa efikasi diri secara signifikan memengaruhi prestasi akademik dan menjadi dasar indikator yang paling kuat atas prediksi performansi dalam tugas-tugas Matematika. Harahap (2012) dalam penelitiannya menyatakan bahwa, efikasi diri siswa sangat menentukan peningkatan prestasi belajar siswa karena dengan efikasi diri, siswa akan mampu merencanakan tindakan, menampilkan perilaku baru, merespon dengan aktif dan kreatif serta mampu memberikan solusi atau memecahkan permasalahan berkaitan dengan tugas yang diberikan guru. Kemampuan tersebut akan melahirkan gambaran diri yang baru dan akan memotivasi siswa dalam pembelajaran untuk mencapai hasil yang maksimal.

Penelitian oleh Pajares dan Usher (2008) menyebutkan bahwa efikasi diri sebagai faktor penentu dari motivasi berprestasi dan perilaku seorang individu. lebih lanjut dikatakan, dalam seting akademik, efikasi diri memengaruhi motivasi, regulasi diri, dan prestasi. Pajares juga melaporkan bahwa efikasi diri dalam pembelajaran regulasi diri dapat memengaruhi motivasi akademik siswa, perilaku, dan penentuan target.

Permasalahan motivasi belajar Matematika pada siswa sering mucul di sekolah. Hal ini dipengaruhi oleh faktor eksternal maupun faktor internal. Faktor 
eksternal antara lain kondisi sekolah yang kurang mendukung baik sarana dan prasarana belajar Matematika, metode guru mengajar, teman sebaya, dan pola asuh. Sedangkan faktor internal yaitu, tujuan belajar, cita-cita, persepsi siswa mengenai kecerdasannya, kemampuan siswa dan keyakinan akan kemampuannya. Dalam penelitian ini, didapatkan sebagian besar peserta mengalami penurunan skor setelah dua minggu pelatihan. Hal ini dapat dipengaruhi oleh faktor lain, seperti kondisi internal siswa (tingkat kecerdasan, karakter, dan daya tahan) maupun dukungan sosial yang diterima siswa baik dari orang tua, sekolah maupun teman sebaya.

\section{KESIMPULAN DAN SARAN}

\section{Simpulan}

Pelatihan efikasi diri dapat meningkatkan motivasi belajar Matematika siswa kelas IX SMP N "X". Hal ini menunjukkan bahwa pelatihan efikasi diri memberikan pengaruh bagi perubahan motivasi belajar Matematika siswa.

Berdasarkan analisis kualitatif didapatkan bahwa siswa mendapatkan beberapa manfaat selama mengikuti pelatihan efikasi diri seperti lebih percaya diri, tidak mudah putus asa dan yakin dapat menyelesaikan soal Matematika serta mencapai nilai Ujian Nasional (UN) Matematika sesuai harapan. Siswa mulai menyukai pelajaran Matematika, mau mengikuti kelas Matematika dan termotivasi untuk belajar Matematika. Siswa mengetahui potensi yang dimiliki dalam Belajar Matematika, membuat rencana belajar Matematika untuk menghadapi Ujian Nasional, mendapat masukan atau umpan balik dari orang lain.

\section{Saran}

Pertama: Rekomendasi kepada pihak sekolah. Disarankan kepada pihak sekolah supaya guru mengikuti pelatihan efikasi diri (training of trainer) agar dapat memberikan pelatihan efikasi diri pada siswa. Selain itu, guru diharapkan mengembangkan pengalaman belajar dan strategi pembelajaran yang menyenangkan, menghidupkan suasana belajar yang interaktif sehingga, mampu memunculkan dan meningkatkan efikasi diri siswa yang pada akhirnya mampu meningkatkan prestasi belajar siswa.

Kedua: Rekomendasi kepada penelitian selanjutnya. Penelitian selanjutnya diharapkan dapat mempertimbangkan pemilihan waktu pelatihan dan sebaiknya tidak dilaksanakan setelah pulang sekolah guna meminimalisir kondisi siswa yang sudah lelah karena aktivitas belajar di sekolah. Peneliti selanjutnya juga diharapkan dapat menyempurnakan penelitian dengan melakukan analisis lebih mendalam melalui penelitian ulang (replikasi penelitian) menggunakan subjek penelitian yang lebih variatif dan mengembangkan atau menambah variable-variabel lain, seperti jenis kelamin, gaya belajar maupun faktor lingkungan.

\section{Ucapan Terima Kasih}

Terima kasih kami sampaikan kepada pengelola Program Magister Psikologi Profesi Universitas Islam Indonesia yang memberi dorongan dan fasilitas untuk lancarnya penyelesaian tesis ini.

\section{DAFTAR RUJUKAN}

Abror, A. R. (2003). Psikologi Pendidikan. Yogyakarta : Tiara Wacana

Alwisol. (2004). Psikologi Kepribadian. Malang : UMM Press

Ariyani, D., \& Supriyanto, S. (2003). Peningkatan Efektivitas Tim Kerja Asuhan Keperawatan Melalui Metode Arung Alam. Jurnal Administrasi, kebijakan, kesehatan 1 (3), 140-145

Azwar, S. (2007). Metode Penelitian. Yogyakarta : Pustaka Pelajar

Azwar, S. 2012. Penyusunan Skala Psikologi. Yogyakarta : Pustaka Pelajar

Bandura, A. (1993). Perceived self Efficacy In Cognitive Development and Functioning. Journal of Educational Psychology, 28(2), 117-148 
Bandura, A. (1994). Self Efficacy. Available (online) :http://www.emory.edu/EDUCATION/ mfp/effbook4.html (diakses pada tanggal 9 Maret 2015)

Bandura, A. (1997). Self Efficacy The Exercise of Control. New York : W.H Freeman and Company

Gaskill, P.J dan Murphy, P.K. (2004). Effects on a Memory Strategy on Second Graders Performance and Self Efficacy. Contemporary

Educational Psychology, 29(1), 27-49

Hamdu, G \& Agustina, L. (2011). Pengaruh Motivasi Belajar Siswa Terhadap Prestasi Belajar IPA di Sekolah Dasar. Jurnal Penelitian Pendidikan, 12 (1), $81-86$

Harahap, D. (2012). Analisis Hubungan anara Efikasi Diri Siswa dengan Hasil Belajar Kimianya. http://digilib.unimed.ac.id/UNIMED (diakses pada tanggal 9 Maret 2015)

Hariyanto, E., Purnomo, R., Bawono, I.R., (2011). Desain Pelatihan, Dukungan Organisasional, Dukungan Supervisor dan Self Efficacy Sebagai Faktor Penentu Keefektifan Transfer Pelatihan. Jurnal Siasat Bisnis, 15 (2), 213 - 227

Hasan, A. B. P; \& Istiqomah. (2011). Hubungan Religiusitas dan Self Efficacy Terhadap Motivasi Berprestasi Pada Mahasiswa Warga Binaan Lembaga Pemasyarakatan Cipinang Jakarta.Jurnal Psikologi, 4 (2), 165 188

Johnson, D. W \& Johnson, F. P. (2001). Joining Together : Group Theory and Group Skills. Boston : Allyn\&Bacon

Mc Cown, R., Priscaoll, M., Ropp, P. G.,(1996). Education Psychology : Learning Centerd Classical Approach Edition 2. Massachussetts: A Simon and Schuster Companis
Mukhid, Abd. (2009). Self Efficacy (Perspektif Teori Kognitif Sosial dan Implikasinya terhadap Pendidikan). Tadris, 4 (1), 106-122

Novariandhini, D.A \& Latifah, M. (2012). Harga Diri, Efikasi Diri, Motivasi Belajar, dan Prestasi Akademik Siswa SMA Pada Berbagai Model Pembelajaran. Jur.Ilm.kel \& Kons., 5 (2), $138-146$

Pajares, P. 2002. Self Efficacy Belief In Academic Contexts : An Outline. http://des.emory.edu/mfp/efftalk.html (diakses pada tanggal 9 Maret 2015)

Pajares, F \& Usher, E.L. (2008). Sources of Self-Efficacy in school : Critical Review of the Literature and Future Directions. Riview of Educational Research, 78 (4), 751 - 796

Priyatno, D. (2012). Belajar Praktis Analisis Parametrik dan Non Parametrik dengan SPSS.Yogyakarta : Penerbit Gava Media

Rohmah, F. A. (2007). Efektivitas Diskusi Kelompok dan Pelatihan Efikasi Diri Untuk Menurunkan Stres Mahasiswa yang Sedang Skripsi.Humanitas, 4 (1), $59-67$

Ruseffendi, E. T. (2006). Pengantar Membantu Guru Mengembangkan Kompetensinya dalam Pengajaran Matematika untuk Meningkatkan CBSA.Bandung : Tarsito

Salas, E.; Fowlkes, J. E.; Stout, R. J.; Milanovich, D. M.; Prince, C. (2001). Does CRM Training Improve Teamwork Skills in the Cockpit?: Two Evaluation Studies. The Journal of the Human Factors and Ergonomics Society June 1999, 41 (2), 326 - 343

Santrock, J. W. (2008). Educational Psychology. Third Edition. New York : McGraw - Hill Companies

Schunk, D. H. (1991). Self Efficacy and Academic Motivation.Educational Psychologist. 26, (3\&4), 207 - 231 
Seniati, L., Yulianto, A., \& Setiadi, B. N. (2005). Psikologi Eksperimen. Jakarta : PT. Tunas Jaya Lestari

Syafitri, A. (2004). Gambaran Aspek-aspek yang Mempengaruhi Prestasi Akademik Pada Siswa SMUN 106 Jakarta yang Berprestasi Akademik Rendah. Jurnal Psikodinamik, 6, 39-57

Syah. (2007). Psikologi Pendidikan Suatu Pendekatan Baru. Bandung : PT. Remaja Rosdakarya

Zimmerman, B. J. (2000). Self efficacy : an essential motive to learn. Contemporary Educational Pscychology, 25, $82-91$ 